\title{
Contingent Control Rights and Managerial Incentives: The Design of Long-term Debt
}

\author{
Zsuzsanna Fluck* \\ Department of Finance \\ Stern School of Business \\ New York University \\ 44 West 4th Street, Suite 9-190 \\ New York, NY 10012 \\ Phone: (212)-998-0341 \\ Fax: (212)-995-4233 \\ e-mail: zfluck@stern.nyu.edu
}

Current version: November 1, 1999

*I am grateful to William T. Allen, Kose John and Yakov Amihud for numerous discussions and encouragement. I thank Franklin Allen, Rob Brokaw, Francesca Cornelli, Doug Diamond, Julian Franks, Denis Gromb, David Hirshleifer, Marcel Kahan, Hayne Leland, Colin Mayer, Stewart Myers, Raghu Rajan, Henri Servaes, Jeremy Stein and René Stulz for helpful comments. This paper benefited from seminar presentations at Carnegie-Mellon University, Dartmouth College, London School of Economics, London Business School, New York University, Oxford University, the University of Pennsylvania and at the 10th Annual Conference on Financial Economics and Accounting at the University of Texas at Austin. 


\begin{abstract}
Enterprises, small or large, rely heavily on long-term financing arrangements to fund their operations. However, it has proved difficult for financial theory to justify the use of long-term contracts when the manager has the ability to divert or manipulate the cash flows, and when it is prohibitively costly for a third party, such as a court, to verify or prove any managerial wrongdoing. Why would investors enter into financial contracts that extend beyond the life of the firm's existing physical assets when such contracts rely on the manager to make repeated investments during the life of the contract? How can investors induce the manager to make these investments when such investments cannot be contracted upon?

In this paper we show that with the appropriate design of the control rights longerterm debt contracts can become sustainable. In particular, investors are willing to hold long-term debt if they are granted (1) the right to dismiss the manager and to take over the company as a going concern upon default; or (2) the right to dismiss the manager and to extend the maturity of the debt in default. Interestingly, it is the threat of dismissal that induces management to comply with the contract but it is the investors' ability to extend the maturity of the debt in default that makes this threat credible. Empirical evidence reported by Gilson (1990, 1993), Gilson, John and Lang (1990), Franks and Torous (1993, 1994), Franks, Nyborg and Torous (1996), Franks and Sussman (1999) supports our view that creditors' right to dismiss manager and to take equity or to extend the maturity of the debt in default plays a key role in enforcing the repayment of debt.

Once we established that long-term debt is sustainable, the natural question to ask is whether investors would be indifferent between long-term debt and outside equity or whether they would prefer one over the other. Despite the strong similarity of the control rights and the maturity of debt and equity, investors will not be indifferent between the two securities in our model. If a project can raise long-term debt it can also raise outside equity but the reverse is not true: there are projects that cannot issue debt but may still obtain outside equity financing. This is so because of the nature of the control rights. Since debtholders have contingent control rights, they cannot exercise control unless default has occurred. Hence, the manager can devise more profitable default strategies by planning his default ahead of time and milking the assets prior to default. Since contingent control rights allow the manager more opportunities for wealth transfer from investors off the equilibrium path than unconditional rights, longterm debt contracts must offer the manager substantially higher incentive payments in equilibrium than equity. Thus, a project aiming to secure longer-term debt financing must show evidence of higher expected profitability than one seeking equity financing.
\end{abstract}

Keywords: security design, nonverifiability of cash flows, managerial moral hazard, control rights, maturity, managerial dismissal, long-term debt, outside equity, managerial asset substitution.

JEL Classification: G34, L14 


\section{Introduction}

Enterprises, small or large, rely heavily on long-term financing arrangements to fund their operations. However, it has proved difficult for financial theory to justify the use of longterm contracts when the manager has the ability to divert or manipulate the cash flows, and when it is prohibitively costly for a third party, such as a court, to verify or prove any managerial wrongdoing. ${ }^{1}$ Why would investors enter into financial contracts that extend beyond the life of the firm's existing physical assets when such contracts rely on the manager to make repeated investments during the life of the contract? ${ }^{2}$ How can investors induce the manager to make these investments when such investments cannot be contracted upon? Despite substantial progress in research on the design of financial contracts (Townsend (1979), Diamond (1984), Gale and Hellwig (1985), Hart and Moore (1989, 1994, 1995), Bolton and Scharfstein (1990), Dewatripont and Tirole (1994), Berglöf and von Thadden (1994), and Berkovitch and Israel (1996)), these questions remain largely open. ${ }^{34}$

\footnotetext{
${ }^{1}$ These two assumptions capture that (1) managerial efforts which are difficult to verify have a significant impact on the firm's cash flows; and (2) the time limits investors face and the legal fees they have to incur when they decide to challenge management in court are frequently beyond their reach.

${ }^{2}$ For a similar definition of long-term debt see Myers (1977).

${ }^{3}$ In this paper we investigate the incentives of managers to make repeated investments during the lives of long-term financial contracts. These incentives are important, since many of the long-term contracts that are observed in practice extend well beyond the lives of the firms' existing physical assets. In the existing literature on short-term versus long-term debt (Berglöf and von Thadden (1994), Hart and Moore $(1994,1995))$ the reinvestment problem does not arise, since these models assume that the maturity of (both short-term and) long-term debt is exogenous and that it is shorter than the life of the firm's assets.

${ }^{4}$ We use the term physical assets to distinguish between the equipment and the goodwill of the company. Goodwill is a potentially long-lived asset whose value critically depends on the manager's actions. If goodwill
} 
When cash flows are nonverifiable, contracts cannot be written on cash flows, since courts cannot verify their true realization (Grossman and Hart (1986)). When management has the ability to divert or manipulate the cash flows, incentive contracts cannot work either (Hart and Moore (1989)). The threat of liquidation can sustain debt contracts (Townsend (1979), Diamond (1984), Gale and Hellwig (1985)) but only with maturity shorter than the life of the firm's existing assets (Hart and Moore (1989), Fluck (1998)). In contrast, the threat of dismissal can sustain outside equity with unlimited life (Fluck (1998)).

In this paper we establish that with the appropriate design of the control rights long-term debt can become sustainable. Our starting point is the model of Fluck (1998). Recognizing that in this model debtholders are limited to liquidate the firm's assets, whereas equityholders are allowed to dismiss the manager, the innovation in our model is to grant debtholders the right to dismiss the manager in the event of a default. It turns out that alone this right can only sustain perpetual bonds, but in combination with other control rights, it can also sustain debt with prespecified maturity.

In particular, if investors are also granted the right to take over the firm as a going concern (take equity) upon default, then they are willing to write debt contracts with maturity longer than the life of the firm's existing physical assets. Similarly, investors are willing to hold long-term debt if they are granted the right to dismiss management and the right to extend the maturity of the debt in default. Interestingly, it is the combination of these rights that makes the contract sustainable. The threat of dismissal induces the manager to comply with is not properly maintained, it can be easily destroyed in a very short period of time. The question we ask here is how can investors induce the manager to maintain the goodwill of the company when investments cannot be contracted upon. 
the contract but it is the investors' ability to take over the firm as a going concern or to extend the maturity of the debt in default that makes this threat credible.

In practice creditors frequently exercise their dismissal rights in default. In a sample of financially distressed companies, Gilson $(1990,1993)$ reports evidence that significant changes take place in the management and the board of directors of these companies following default. Gilson finds that on average 54 percent of directors who sit on the board prior to the onset of financial distress and 57 percent of the CEOs are replaced by the time their firms emerge from bankruptcy or settle privately with creditors less than two years later. Although the average age of departing managers is only 52 years, none of them hold a senior management position at another exchange listed firm during the next three years. Consistent with our theory, Gilson's evidence suggests that debtholders use their dismissal rights to induce the repayment of debt from managers.

In line with our theory, the debtholders' rights to take equity or to extend the maturity of the debt also play an important role in Chapter 11, in private debt restructuring, and in the UK bankruptcy procedure (Gilson (1993), Franks and Torous (1993, 1994), John (1993), Franks, Nyborg and Torous (1996) and Franks and Sussman (1999)). One important feature of Chapter 11 is that when the firm enters the reorganization the maturity of the debt is extended and all repayments of capital and interest are postponed until the reorganization is complete. Under Chapter 11 the firm's impaired debts are replaced with new financial claims (longer-term debt or equity) on the assumption that the firm will remain a going concern. In private debt restructuring creditors consent to reduce promised interest or principal payments, extend the maturity, or accept equity securities in the firm. The UK bankruptcy is characterized by a great concentration of rights under a security called the 
floating charge. The floating charge closely resembles to equity with full control. In default, the floating charge holder may appoint a receiver and take possession of the company. All the authority of the manager and the board of directors passes to the receiver, who may close the company, sell its assets and do as he wishes in order to repay the loan.

Gilson (1990) and Gilson, John and Lang (1990) report evidence that in practice creditors frequently accept equity securities in default. In approximately three out of four firms in Gilson's (1990) sample, creditors receive significant blocks of voting stock under the firms' debt restructuring and Chapter 11 reorganization plans. On average banks receive 36 percent and bondholders receive 33 percent of the firms' common stock. In a number of cases, the debtholders also appoint their representatives to the board of directors. In $74 \%$ of the firms in Gilson, John and Lang's (1990) sample of corporate workouts, creditors take new equity securities. In $51.4 \%$ of the debt restructurings bank lenders receive equity in the firm, while holders of publicly traded debt are given equity securities $86.7 \%$ of the time. Extensions of debt maturity is observed in 49\% of workouts. The evidence reported in Gilson (1990) and Gilson, John and Lang (1990) supports our view that the creditors' right to take voting equity or to extend the maturity of the debt in default plays a key role in enforcing the repayment of debt.

In the second part of the paper, we focus on the choice between debt and equity. Once we established that long-term debt is sustainable, the natural question to ask is whether investors would be indifferent between long-term debt and outside equity or whether they would prefer one over the other. Given the strong similarity of the control rights and the maturity of debt and equity, one would expect the Modigliani and Miller indifference result to prevail. After all, the equivalent of a strategic default on the debt payment would be the 
manager's failure to pay equilibrium dividends to equity, and in either case, the equilibrium strategy would specify that investors dismiss the manager. Surprisingly, however, in our model investors will not be indifferent between the two securities. If a project can raise long-term debt, it can also raise outside equity but the reverse is not true. This is so because of the nature of the control rights. Debtholders have contingent control rights, so they cannot exercise control unless default has occurred. Hence, the manager can devise more profitable default strategies by planning his default ahead of time and milking the assets prior to default. Since contingent control rights allow the manager more opportunities for wealth transfer from investors off-the-equilibrium path than unconditional rights, long-term debt contracts must offer the manager substantially higher incentive payments in equilibrium than equity. ${ }^{5}$ Thus, a project aiming to secure longer-term debt financing must show evidence of higher profitability than one seeking equity financing. ${ }^{6}$

\footnotetext{
${ }^{5}$ In their study of managerial compensation and capital structure of firms, Berger, Ofek and Yermack (1997) report that managers enjoy more attractive compensation packages in firms that use more debt financing. Since our theory implies that firms that use long-term debt must offer higher incentive payment to managers than those that use outside equity, their findings are consistent with the thrust of our model.

${ }^{6}$ Since the seminal papers of Jensen and Meckling (1976), Myers (1977), Smith and Warner (1979) and Berkovitch and Kim (1990) the agency problem between managers and bondholders has been a central issue in the corporate finance literature. The manager may choose investments that benefit him at the expense of creditors, or he may transfer wealth from debtholders by rejecting profitable investments. Examples of managerial actions include risk-shifting (shifting into a riskier project with identical or lower net present value), asset switching (failing to maintain the assets, or failing to buy proper insurance) and the effort provision problem (when effort is costly the manager may pass up investment opportunities that are valuable to the firm but costly to the manager). For an interesting study on the impact of risk-shifting on optimal design of claim structures when managerial investment policy is nonverifiable see Nachman and Noe (1996).
} 
As a consequence, investors will not be indifferent between debt and outside equity, regardless of the maturity of the debt contract. There will be projects which cannot raise long-term debt but may still obtain outside equity financing. ${ }^{7}$ These are projects with relatively high cash flow variability and/or relatively low expected profitability. Consistent with Barclay and Smith (1995), as firms show higher profitability, they can secure long-term debt financing in our model.

Related literature discusses at least three ways for financiers to protect their investment from strategic default by managers. A financier may rely on his reputation, on an exante commitment, or on his control rights to enforce his claim. A banker can establish a reputation for penalizing entrepreneurs who fail to deliver. Building such reputation may be costly for the banker himself in the short run, but will pay off in the long run by changing the expectations of future clients and thereby preventing strategic defaults. This strategy is particularly suitable for a financier who has a recognizable presence but not suitable for a bondholder who is just one of many unidentifiable investors. Boot, Greenbaum and Thakor

\footnotetext{
${ }^{7}$ In the corporate finance literature it has been frequently stated that equity is equivalent to debt with an infinite payment since such debt contract would trigger immediate default. It follows from our theory that this statement only holds in continuous time models i.e. in models where default occurs instantenously. In discrete time models, in contrast, where the repayment of debt is due at a certain date in the future, the manager can plan his default ahead of time and milk the assets prior to default. The debtholders recognize this but they cannot prevent it, since their control rights can only be exercised upon default. This is true regardless of the size of the promised debt payment. Since contingent control rights allow the manager more opportunities for wealth transfer from investors off-the-equilibrium path than unconditional rights, there will be projects which can raise outside equity but cannot issue debt even by promising an infinite payment. As a consequence, the two contracts will not be equivalent.
} 
(1993) and Chemmanur and Fulghieri (1994a, 1994b) develop models in which banks benefit in the long run from having well-established reputations.

A banker can also prevent strategic default by committing ex ante to refinance any entrepreneur with good performance in the prior period (even if such refinancing would not be subgame perfect ex post) but terminate funding if the entrepreneur has defaulted in the prior period. While she may be tempted to terminate more projects ex post, the banker would benefit from having made the commitment not to do so ex ante, since her commitment will induce all the entrepreneurs to truthfully report their profits. Bolton and Scharfstein (1990) present an optimal debt contract with these characteristics in a model where firms borrow and the design of the debt contract induces predatory behavior from rivals.

Alternatively, if investors hold control rights, then they can prevent strategic default by threatening to dismiss the manager or liquidate the firm. Thus, investors who cannot build reputations or make commitments because they do not have a recognizable presence on the market may still protect their investment with appropriately designed control rights. Townsend (1979), Diamond (1984), Gale and Hellwig (1985), Aghion and Bolton (1990), Berkovitch and Israel (1996), Fluck (1998) and Myers (1998) developed models in which investors enforce their claims by exercising control rights. Our paper belongs to this class of models.

The paper is organized as follows. In Section 2 we describe the model. In Section 3.1, 3.2 and 3.3 we present three equilibrium designs of long-term debt. In Section 4 we discuss the empirical implications of the contract designs. In Scetion 5 we compare the profitability constraints for long-term debt and outside equity. The conclusions are summarized in Section 6. The proofs of the propositions are contained in the Appendix. 


\section{The Model}

Consider a risk-neutral (entrepreneur)-manager who has no wealth and seeks financing for a project from risk-neutral investors. Both the investors and the manager use the same positive discount factor, $\delta$, to value future payoffs, and both care only about monetary payoffs. Investors are Bertrand competitors, willing to finance projects if they break even.

The project yields a periodic operating cash flow, $\tilde{v}$. We denote the cash flow realization at time $\mathrm{t}$ by $v_{t}$. The cash flow, $\tilde{v}$, is an i.i.d. random variable that takes on the values $v+x>0$ and $v-x>0$ with equal probabilities. The project requires an investment outlay, $I$, and involves the operation of an equipment with economic life of two periods.

Each period, the manager can divert the cash flows as private benefits, and in each period, investors and management both learn the true realization of the cash flows. However, the true realization of the cash flows is assumed to be nonverifiable by a third party, since contracts written on cash flows are prohibitively costly to verify in court.

\subsection{Investment policy}

The project can be repeated over and over again. As long as the project continues, the manager can renew the equipment each period at some cost $a=\frac{\delta I}{1+\delta}$, or alternatively, he can divert $a$ and raise new financing every two periods. ${ }^{8}$ The equipment can be periodically

\footnotetext{
${ }^{8}$ Worth mentioning that in our model there are projects that cannot raise long-term debt financing unless the debtholders can induce the manager to periodically renew the assets. These are projects that are not profitable enough to compensate the firm for the excessive perks the manager consumed in the past at the expense of the investment. Since in our model the cash flows the manager has diverted are consumed right away (see Bolton and Scharfstein (1990) for a discussion of this assumption), the equilibria in which the manager periodically maintains the assets dominate all other equilibria in the sense of Gale and Hellwig
} 
renewed if all cash flow realizations of the project exceed the cost of the renewal, that is, if $v-x \geq a$. If $a$ is spent at time 1 and 2 then further investment of $I$ can be avoided. However, if $a$ is not spent at time 1 and time 2, then, unless $I$ is invested, the assets cannot produce.

Investors know whether or not the equipment has been renewed. This managerial investment policy is also nonverifiable for a third party, such as a court. ${ }^{9}$ As a general principle, in this model only receipts of payments are verifiable. We assume that the true realization of all other financial and accounting variables are prohibitively costly to verify.

\subsection{The debt contract}

We define debt as a contract that grants investors a fixed periodic payment and contingent control rights. The debholders' control rights can only be exercised in default, i.e. if the manager has failed to make the agreed-upon payment. ${ }^{10}$ In default, (i) the debtholders can (1985). For this reason, we will focus only on equilibria in which investors can induce the manager to renew the assets each period and ignore the equilibria in which the manager revisits the capital market every two periods. In Section 4 we will point out that if the manager can save the cash flows that he diverted and invest his funds into new assets every two periods, then the same incentive compatibility conditions that induce him to periodically renew the assets will induce him to plow his funds back into the firm every two periods.

${ }^{9}$ As the following quote from Kahan and Tuckman (1996) (Page 16) illustrates, the managerial investment policy is also difficult to verify in practice. "Public indentures contain a covenant which requires companies to keep their properties in working order and to make all necessary repairs... What constitutes "good working order" and "necessary repairs" is nowhere specified.... [This covenant] further provides that "the judgement of the Company" shall determine what constitutes good working order and what repairs are necessary. Given the broad discretion afforded to the company's management, the American Bar Foundation (1971) concludes that "this [covenant] is not likely to have any play except under very adverse business conditions"."

${ }^{10}$ Alternatively, if some accounting variables were verifiable in our model, then we could define default as 
forgive $^{11}$ and extend the maturity of the debt, or (ii) they can dismiss the manager, and/or take over the firm as a going concern, or (iii) they can dismiss the manager and extend the maturity of the debt ${ }^{12}$. These actions and their payoff-implications are described in details in the next subsection.

A debt contract may be written with a prespecified maturity, $\mathrm{T}$, or with indefinite maturity. If T exceeds the life of the firm's existing physical assets (in our model it is two periods) then we call the contract long-term debt.

\subsection{Outside equity}

In exchange for an effective claim to the firm's cash flows net of the manager's private benefits of control and unconditional control rights - the right to dismiss the manager regardless of the firm's cash flows or managerial performance - outside equity holders transfer $I$ to the manager. Equity is issued with indefinite life. ${ }^{13}$ The timing of the actions and the associated payoffs for outside equity are described in the next subsection.

either failure to make payment or violation of a bond covenant. Our results are easily applicable to covenant debt, since investors are frequently granted specific control rights when a covenant is violated (Smith and Warner (1979) and Kahan and Tuckman (1996)).

${ }^{11}$ In practice, creditors frequently forgive by waiving violations of covenants (Beneish and Press (1993), Chen and Wei (1993) and Sweeney (1994)).

${ }^{12}$ In the corporate world when there is default, creditors obtain de facto veto power over any corporate action (Amihud, Garbade and Kahan (1999)). In our model a de facto veto power is equivalent with taking over the company as a going concern.

${ }^{13}$ Fluck (1998) established that when cash flows are nonverifiable and the manager has the ability to divert or manipulate the cash flows, then the only outside equity that is sustainable is of unlimited life. This is because the threat of the manager's dismissal is not a credible threat when there is a prespecified expiration date on equity but becomes a credible threat when the equity has indefinite life. 


\subsection{The set of actions and payoffs}

Figure 1 presents the set of actions and payoffs when investors have the contingent right to dismiss management and take over the firm as a going concern in the event of a default. As long as the manager is in charge, he decides on the investment and makes payments to investors. Investors receive $p_{t}$, the (actual) payment on which the manager has decided and the manager receives $M_{t}=v_{t}-a_{t}-p_{t}$ or $v_{t}-p_{t}$, depending on his investment.

If default occurs and the debtholders forgive the current payment and extend the maturity of the debt by one period, then the remaining $(\mathrm{T}+1-\mathrm{t})$ payments are rescheduled to times $\mathrm{t}+1, \ldots, \mathrm{T}+1 .{ }^{14}$

Alternatively, if the debtholders dismiss the manager upon default, then a new manager takes charge and decides on the payments $\hat{p}_{t}$ and the investment $\hat{a}_{t}$. The departing manager receives no payoff and the investors bear $c$, the cost of replacing the manager.

If the debtholders take over the firm as a going concern at the time of the default, then from this date onward they will be holding unconditional control rights for the indefinite future and they will have a claim to a fraction of the firm's cash flows. That is, they will receive an equity stake in the company. We denote the discounted present value of the debtholders' future payoff from the time they have taken over the company as a going concern by $\frac{E \hat{p}^{+}}{1-\delta}$, which is equal to the value of the debtholders' remaining claim (or the value of the firm whichever is lower).

If the debtholders dismiss the manager but do not take equity in default, then they can still reschedule the remaining $(\mathrm{T}+1-\mathrm{t})$ payments to times $(\mathrm{t}+1, \ldots \mathrm{T}+1)$ and they will hold

\footnotetext{
${ }^{14}$ Alternatively, if the debtholders forgive but do not extend the maturity of the debt, then they simply agree to accept one less payment.
} 
unconditional control rights until the debt is paid off.

Notice from Figure 1 that it is the manager who has the first-mover advantage in our model of debt. This is so because investors have contingent control rights. Thus, they can act only in the event of a default. But whether or not default will occur, it is determined by the manager's prior choice of action (strategic default) and by the state of nature (liquidity default).

By definition, outside equityholders can act regardless of the manager's actions. Hence, when equityholders finance the project, they have the first-mover advantage: They can dismiss the manager regardless of performance. When the project is financed by outside equity the payoffs are as follows. As long as the manager is in charge, he decides on the investment and makes payments (dividends) to investors. Investors receive $d_{t}$, the (actual) payment on which the manager has decided and the manager receives $M_{t}=v_{t}-a_{t}-d_{t}$ or $v_{t}-d_{t}$, depending on his investment. If the equity holders dismiss the manager, then a new

manager takes charge and decides on the payments $\hat{d}_{t}$ and the investment $\hat{a}_{t}$. The departing manager receives no payoff and the equityholders bear $c$, the cost of replacing the manager.

\section{The Design of Long-term Debt}

In this section we will show that with appropriate design, debt contracts with maturity longer than the life of the firm's physical assets are sustainable. We will derive three equilibrium contracts. These contracts induce managers to make periodic debt payments in equilibrium and to properly maintain the assets/goodwill of the company. All three are Pareto-optimal. They involve no verification cost or deadweight loss in equilibrium and the only way to make 
one party better off is at the expense of the other party. These contracts all rely on the investors' right to dismiss management and their ability to extend the maturity of the debt in default. ${ }^{15}$

It is straightforward to see that the right to dismiss the manager in default is not sufficient to sustain a debt claim with T-period maturity. If the manager is going to be fired following a default, then, depending on the discount rate and the profitability of the project, it is in his best interest to comply with the contract in the last period. After all, once the contract expires, he will remain in charge and he can decide whether or not to continue the project. Alternatively, if the manager is not going to be disciplined for defaulting in the last period, then it is in his best interest to strategically default then. Similarly, the manager would not divert the cash flows in the second-to-last period (and in any of the preceeding periods), if he knew he would be replaced following default. Otherwise, he would divert all the cash flows. Thus, if the threat of dismissal is credible, the manager will comply with the terms of the contract.

However, when debt has a prespecified expiration date, the threat of dismissal is not

\footnotetext{
${ }^{15}$ Models in the earlier literature focused on three types of control rights: the right to liquidate the firm's physical assets, the right to stop future funding for managers and the right to dismiss the manager. This literature has established that the investors' right to liquidate the physical assets of the company in default can sustain one-period debt (Townsend (1979), Diamond (1984), Gale and Hellwig (1985), Hart and Moore (1989)) but cannot sustain debt with maturity equal or longer than the life of the firm's physical assets (Hart and Moore (1989), Fluck (1998)) and that investors' right to stop future funding for managers in default can induce these managers to make the first payment on a two-period debt contract (Bolton and Scharfstein (1990)). More recently, Fluck (1998) showed that the unconditional right to dismiss management can sustain outside equity but only with unlimited life.
} 
credible. When dismissal is costly, debtholders will not discipline the manager in the last period. This is so because with unverifiable cash flows, debtholders cannot recover the missed payment from the manager. Thus, the manager will strategically default in the last period. Recognizing that any incoming manager will default in the last period, debtholders will discipline the manager neither in the second-to-last period nor in any preceeding period. Hence, regardless of $\mathrm{T}$ finite, the debt contract will unravel.

If, however, the debtholders' right to dismiss management is combined with (i) the right to take over the firm as a going concern (take equity) in default (section 3.1) or (ii) the right to extend the maturity of the debt in default (section 3.2), or (iii) if the debt is written with indefinite maturity (section 3.3), then the threat of dismissal can become credible. By design, each of these contracts has indefinite maturity in default. Since it is the expiration date that causes the unravelling of the contract, one way to design an equilibrium contract is to allow investors to extend the maturity of the debt in default.

\subsection{The right to take over the firm as a going concern in default}

In this section we will show that if the debtholders are given the right to dismiss the manager and to take over the firm as a going concern (take equity) in default, then the threat of dismissal may become credible. When investors have the contingent right to dismiss management and take over the firm as a going concern, then the following strategy-pair, as proved in Proposition 1, constitutes a subgame perfect equilibrium.

For the investors: (i) Investors replace the manager and take over the firm in a strategic default $^{16}$ in period $t$ and forgive him and extend the maturity of the debt in a liquidity default

\footnotetext{
${ }^{16}$ Note that this equilibrium does not specify any action for investors if the manager has paid the contrac-
} 
in period $\mathrm{t}^{17}$ (ii) If the manager has strategically defaulted in period t but he has not been dismissed in this period and/or the firm has not been taken over, then the investors will dismiss him and will take over the firm next period regardless of the payment made; (iii) If the manager was dismissed in a liquidity default in period t or the firm has been taken over, then the investors will dismiss the new manager and will take over the firm next period; (iv) If investors have dismissed the manager and have taken over the firm in a liquidity default in period t, then they will replace the manager and will take over the firm in any strategic default thereafter and will forgive him and extend the maturity of the debt in any liquidity default $^{18}$ thereafter; $^{19}$ (v) If there is a liquidity default in period $\mathrm{t}$ and investors forgive but do not extend the maturity of the debt, then from then on (i) takes effect.

For the manager and the new manager: (a) If a (new) manager has not strategically defaulted until period t, then he will not strategically default in period t; (b) if the manager finds himself on the job immediately following a strategic default in period t, then he will tually specified amount, since the debtholders hold contingent rights and therefore, they are not allowed to take action unless default has occurred.

${ }^{17}$ Replacing the manager after a strategic default, but not replacing him after a liquidity default, dominates any alternative equilibrium specification in the sense of Gale and Hellwig (1985). Investors' willingness to forgive the manager in liquidity default is largely consistent with empirical evidence reported by Beneish and Press (1993), Chen and Wei (1993) and Sweeney (1994).

${ }^{18}$ After the debtholders have taken over the company as a going concern, strategic default and liquidity default are defined as failure to pay equilibrium dividends for strategic and for liquidity reasons, respectively.

${ }^{19}$ In equilibrium, the choice of actions by the investors depends on the corresponding actions by the new manager. Investors take different actions in (iii) and (iv) because the new manager cannot tell whether a default that preceeded his appointment was a strategic or a liquidity default. We impose this assumption to be consistent with our earlier assumptions on what third parties know and what they do not know. 
continue to divert the cash flows thereafter; (c) If the manager has been replaced in period t but the company has not been taken over by the debtholders, then the new manager will divert the cash flows each period thereafter; (d) If the manager has been replaced in period t and the company has been taken over by the debtholders, then the new manager will not strategically default in the following period.

Interestingly, it is the combination of the debtholders' right to dismiss management and their ability to take over the firm as a going concern that makes long-term debt sustainable. Having the right to dismiss the manager, investors can induce the manager to comply with the contract and can prevent strategic default. It is, however, their ability to take over the firm as a going concern for indefinite life that makes this threat credible. Having the right to take over the firm as a going concern for the indefinite future, investors are willing to dismiss the manager in strategic default, since $-c+E \hat{p}+\frac{\delta E \hat{p}^{+}}{1-\delta}$, the going-concern value of the firm for investors if they dismiss management, exceeds zero, the going concern value of the company for investors if they do not dismiss management. This is true regardless of the maturity of the original debt contract.

The incentive compatibility conditions are presented below and in the Appendix. Investors are willing to provide the necessary funds to the manager if they can recover their investment. Formally, $\forall 0 \leq \tau<T$

$$
E p \sum_{t=\tau+1}^{T} \delta^{t-\tau} \geq I .
$$

The left hand side of the inequality shows the present value of the actual payments investors expect to receive along the equilibrium path, the right hand side shows the investment 
outlay the debtholders provide.

It is incentive compatible for the manager to comply with the terms of the contract if the discounted present value of his future incentive payments in equilibrium exceeds the value of the current cash flows. That is, if $\forall 0 \leq \tau<T$

$$
M_{v+x}+E M \sum_{t=\tau+1}^{T} \delta^{t-\tau}+\delta^{T+1-\tau} M^{\infty} \geq v+x
$$

and

$$
M_{v-x}+E M \sum_{t=\tau+1}^{T} \delta^{t-\tau}+\delta^{T+1-\tau} M^{\infty} \geq v-x
$$

where $M_{v+x}$ and $M_{v-x}$ are the equilibrium payoffs to the manager in case of no liquidity default (good state) and in liquidity default (bad state), respectively. $E M$ denotes the expected periodic payoff the manager receives during the life of the contract. $M^{\infty}$ is the period- $(\mathrm{T}+1)$ discounted value of the manager's expected future payoffs after the contract has expired.

There are two additional incentive compatibility conditions required for the manager. When investors have contingent control rights, they can only discipline the manager upon default. In particular, debtholders cannot replace the manager for failing to maintain the firm's assets. Recognizing this, the manager can devise a two-step default strategy: in the first period he would make the contractual payment but would not maintain the assets and would divert $a$. Then, he would divert all the cash flows in the second period. Consequently, for the manager to comply with the contract, it must be the case that in addition to (1), (2), and (3), the following conditions also hold $\forall 0 \leq \tau<T$ : 


$$
\begin{aligned}
& M_{v+x}+E M \sum_{t=\tau+1}^{T} \delta^{t-\tau}+\delta^{T+1-\tau} M^{\infty} \geq a+\delta v \\
& M_{v-x}+E M \sum_{t=\tau+1}^{T} \delta^{t-\tau}+\delta^{T+1-\tau} M^{\infty} \geq a+\delta v .
\end{aligned}
$$

The left hand sides of (4) and (5) show the payment the manager receives along the equilibrium path, the right hand sides show the amount he can divert: the sum of the investment in the current period and the present value of the expected cash flows next period..$^{20}$

Proposition 1 summarizes the equilibrium contract described above. The proof is presented in the Appendix.

Proposition 1 Investors are willing to hold debt with maturity longer than the life of the firm's existing physical assets if they are granted the right to dismiss the manager and to take over the company as a going concern upon default.

\section{Section 3.2 The right to extend the maturity of the debt in default}

The right to take over the firm as a going concern is not the only right that can assure the credibility of the dismissal threat. The manager can instead grant the debtholders the

\footnotetext{
${ }^{20}$ In our model we assumed that the cash flows the manager has diverted are consumed right away. Notice, however, that if the manager could save the cash flows that he diverted and invest his funds into new assets every two periods, then conditions (4) and (5) would assure the manager's willingness to plow his funds back to the firm. Since $v-x \geq a$ (see basic model), therefore $a+\delta a \leq a+\delta v$, and $\delta I \leq a+\delta v$. Hence, it follows from (4) and (5) that $\delta M_{v+x}+\delta E M \sum_{t=1}^{T} \delta^{t}+\delta^{T+1} M^{\infty} \geq I$ and $\delta M_{v-x}+\delta E M \sum_{t=1}^{T} \delta^{t}+\delta^{T+1} M^{\infty} \geq I$. The last two inequalities guarantee that the the manager is willing to plow his funds back to the firm.
} 
right to extend the maturity of the debt upon default. When they are granted this right, the debtholders can extend the maturity of their contract every time default occurs. Thus, they will be holding unconditional rights with indefinite maturity in default. These rights can prevent the unravelling of the contract.

When investors are granted the right to dismiss the manager and extend the maturity of the debt in default then the following strategy-pair, as proved in Proposition 2, constitutes a subgame perfect equilibrium.

For the investors: (i) Investors replace the manager and extend the maturity of the debt in a strategic default in period $t$ and forgive the manager and extend the maturity of the debt in a liquidity default in period t; (ii) If the manager has strategically defaulted in period $\mathrm{t}$ but he has not been dismissed in this period or investors have failed to extend the maturity of the debt, then the investors will dismiss him and will extend the maturity of the debt next period regardless of the payment made; (iii) If the manager was dismissed in a liquidity default in period t but the maturity of the debt has not been extended, then the investors will dismiss the new manager and will extend the maturity of the debt next period; (iv) If there is a liquidity default in period $t$ and investors have dismissed the manager and extended the maturity of the debt or they forgave the manager and did not extend the maturity of the debt, then from then on (i) takes effect.

For the manager and the new manager: (a) If a (new) manager has not strategically defaulted until period $t$, then he will not default in period $t$; (b) if the manager finds himself on the job following a strategic default in period t, then he will continue to divert the cash flows thereafter; (c) If the manager has been replaced upon default in period t but the maturity of the debt has not been extended by the debtholders, then the new manager 
will divert the cash flows each period thereafter; (d) If the manager has been replaced immediately upon default in period t and the maturity of the debt has been extended, then the new manager will not strategically default in the following period.

For this contract to be incentive compatible for the investors and the manager it must be the case that (1), (2), (3), (4) and (5) are satisfied. Proposition 2 summarizes the equilibrium contract described above. The proof is presented in the Appendix.

Proposition 2 Investors are willing to hold debt with maturity longer than the life of the firm's existing physical assets if they are granted the right to dismiss the manager and to extend the maturity of the debt upon default.

\subsection{Perpetual bond}

Another way to make the dismissal threat credible is to issue a claim for indefinite life (perpetual bond). Interestingly, this contract is sustainable even in the absence of any recovery right. Investors are willing dismiss the manager in strategic default, since $\frac{\delta p}{1-\delta}-c$, the value of their claim if they dismiss the manager, exceeds 0 , the value of their claim if they do not dismiss the manager. ${ }^{21}$

\footnotetext{
${ }^{21}$ Another contract with no recovery rights is presented in Bolton's and Scharfstein's (1990) model. In their model of two period projects, the projects require new outlay each period. The only right the investors have is to deny funding for the entrepreneur's next project. Since in the second period the project will be over and the investors cannot enforce any payment from the managers, at the end of period 1 no investor would provide new funding for any period-2 project. In equilibrium the investors and the entrepreneur agree to a two-period contract in which the investors automatically provide the entrepreneur with new funds in the second period (even though it is not subgame perfect for them to do so) unless default occurs in the first
} 
When the manager issue perpetual debt, the following strategies, as proved in Proposition 3, constitute a subgame perfect equilibrium in which the manager will make periodic debt payments and will properly maintain the firm's assets.

For the investors: (i) Investors do not dismiss the manager at first and until no strategic default occurs; (ii) In the event of a strategic default in period t, investors replace the manager; (iii) If the manager has strategically defaulted in period t but he has not been dismissed in this period, then investors will dismiss him next period regardless of the payment made.

For the manager and the new manager: (a) If a (new) manager has not strategically defaulted until period $t$, then he will not default in period t; (b) If the manager finds himself on the job following a strategic default in period t, then he will continue to divert the cash flows thereafter; (c) If the manager has been replaced upon default in period t and the company has been taken over by the debtholders, then the new manager will not strategically default in the following period.

For this contract to be incentive compatible it must be the case that

$$
\begin{aligned}
& M_{v+x}+\frac{\delta E M}{1-\delta} \geq a+\delta v \\
& M_{v-x}+\frac{\delta E M}{1-\delta} \geq a+\delta v .
\end{aligned}
$$

period. This contract will induce the entrepreneur to make payment at the end of the first period but he will always default in the second period. In contrast to our model where dismissing the manager is costly for the investors, in Bolton's and Scharfstein's model the creditors gain from denying funding for the entrepreneur in the second period. 
also hold in addition to

$$
\begin{gathered}
\frac{\delta E p}{1-\delta} \geq I \\
M_{v+x}+\frac{\delta E M}{1-\delta} \geq v+x \\
M_{v-x}+\frac{\delta E M}{1-\delta} \geq v-x .
\end{gathered}
$$

Conditions (6) and (7) capture the notion that the manager may start milking the assets prior to default.

Proposition 3 summarizes the equilibrium contract described above. The proof is presented in the Appendix.

Proposition 3 Investors are willing to hold a perpetual bond if they are granted the right to dismiss the manager upon default.

\section{Empirical Implications}

The contracts described in Proposition 1 and 2 rely on the debtholders' right to take over the firm as a going concern in default and their right to extend the maturity of the debt, respectively. These rights also play an important role in practice: in Chapter 11, in private debt restructuring, and in the UK bankruptcy procedure (Gilson (1993), Franks and Torous (1993, 1994), John (1993), Franks, Nyborg and Torous (1996) and Franks and Sussman (1999)). Under Chapter 11 the firm's impaired debts are replaced with new financial claims 
(longer-term debt or equity) on the assumption that the firm will remain a going concern. In private debt restructuring creditors consent to reduce promised interest or principal payments, extend the maturity, or accept equity securities in the firm. ${ }^{22}$ In the UK, bankruptcy is characterized by a great concentration of rights under a security called floating charge that closely resembles to equity with full control. In default, the floating charge holder appoints a receiver and takes possession of the company. All the authority of the manager and the board of directors passes to the receiver, who may do as he wishes in order to repay the loan.

In line with our theory, in practice debtholders also rely on their dismissal rights to induce the repayment of debt from future managers. In a sample of financially distressed firms, Gilson (1993) finds that on average 57 percent of the CEOs are replaced by the time their firms emerge from bankruptcy or settle privately with creditors less than two years later. Although the average age of departing managers is only 52 years, none of them hold a senior management position at another exchange listed firm during the next three years. Gilson's evidence indicates that dismissal is a credible threat: managers lose substantially more than their current pay and perks when they are dismissed in corporate default.

It is interesting to compare the timing of the manager's dismissal in our equilibrium contracts and in the different restructuring procedures in practice. In the equilibrium strategies in Section 3.1, 3.2 and 3.3, the manager is dismissed upon default. This is very similar to

\footnotetext{
${ }^{22}$ In Gilson's (1990) sample of financially distressed firms, in approximately three out of four firms in the sample, creditors receive significant blocks of voting stock under the firms' debt restructuring and Chapter 11 reorganization plans. On average banks receive 36 percent and bondholders receive 33 percent of the firms' common stock. In a number of cases, the debtholders also appoint their representatives to the board of directors.
} 
the UK bankruptcy procedure but it differs from Chapter 11. In the UK receivership all the authority of the manager and the board of directors passes to the receiver. In Chapter 11 the manager has the right to submit the first reorganization plan and he cannot be dismissed until then.

The protection that Chapter 11 provides for the manager can easily be incorporated into our equilibrium contracts by redefining the equilibrium strategies for the investors in Section 3.1, 3.2 and 3.3. For example for Section 3.1 the new equilibrium strategy would specify: If the manager has strategically defaulted in period $\mathrm{t}$ and filed for Chapter 11, then debtholders will dismiss the manager and will take over the company as a going concern as soon as they can, regardless of the plan submitted by the manager. This contract is also an equilibrium contract in our model. But because investors do not replace the manager immediately in a strategic default, this equilibrium is dominated by our original equilibrium in the sense of Gale and Hellwig (1985). As a consequence, fewer projects can raise long-term debt when the manager can enjoy the protection of Chapter 11.

There are three important conditions embedded in Proposition 1. First, debtholders cannot be given more than the value of their remaining claim when they take over the company. Otherwise, they would take over the company too often (even in the case of liquidity default), and would thereby destroy the manager's incentive to comply with the contract.

Second, if debtholders decide to take equity positions in the firm upon default, then they must be able to dismiss the manager regardless of how small their claims are. Hence the equity contract that will take effect once debtholders have taken over the firm will 
occasionally violate the one-share one-vote principle. ${ }^{23}$ A good example of such an equity contract from practice is the UK receivership. As we mentioned before, the UK bankruptcy is characterized by a great concentration of rights under a new security called floating charge which closely resembles to equity with full control. By construction, this equity contract almost always violates the one-share one-vote principle.

Finally, it is worth to point out that the contract described in Proposition 1 potentially relies on debtholders' willingness to take equity positions following a default. Therefore, this contract cannot be held by investors, who are prohibited from taking equity positions in firms. $^{24}$

An interesting implication of all three propositions is that only projects with indefinite growth opportunities can raise longer-term financing. The empirical evidence on the relationship between growth opportunities and debt maturity is mixed. Smith and Warner (1995) document that firms with few growth opportunities use longer maturity debt. In contrast, Stochs and Mauer (1996) report that the higher the market to book ratio is, the longer the maturity of the firm's debt. Since our paper is silent on the size of the growth opportunities of the firm, neither finding is inconsistent with our model.

\footnotetext{
${ }^{23}$ This is equivalent of the creditors obtaining de facto veto power over any corporate action in default (Amihud, Garbade and Kahan (1999), see also in footnote 12).

${ }^{24}$ The Banking Act of 1933 (12 U.S.C. 24) prohibits US commercial banks to hold equity shares. An important exception to this general prohibition is the authority of banks to take equity in corporate restructurings. Nevertheless, the Bank Holding Company Act of 1956 prohibits banks from owning more than 5 percent of the voting stock in any nonbank company or from otherwise controlling an industrial firm. They can, however, jointly hold more than 5 percent. For an interesting study on the banks' willingness to take stock in restructurings see James (1995).
} 
Our model also implies that the maturity of debt will be matched with the going concern life of the company as opposed to the life of the firm's existing physical assets. In particular, the model implies that the maturity of the debt will be shorter than the going concern life of the company. In practice, it is difficult to estimate the going concern life of a company. One interesting exception is the case of the UK's utilities. In the UK regulators sign operating contracts with utility companies. These contracts give the companies the right to operate in a region for a fixed number of years, typically four or five years. These contracts are useful for our purposes because their length can be used as a proxy for the going concern lives of these companies. Consistent with our theory, even though the utilities have relatively long-lived physical assets, the maturity of their debt is not matched with the life of their existing physical assets: it is matched instead with their going concern life, i.e. with the duration of their operating contract (Mayer (1999)).

It is possible to extend the model to study risk-shifting by modifying the specification of the investment policy as follows: "If $a$ is not spent in period 1 and period 2 , then with probability $(1-\epsilon)$ the assets can not produce any cash flows unless $I$ is invested, but with probability $\epsilon$ small, the assets can produce for another period. For a wide range of parameter values the newly modified managerial strategy of skipping the investment and milking the assets will have lower NPV and higher variance for the firm than the strategy of properly maintaining the firm's assets. Hence, the new model is suitable for the study of risk-shifting. It is easy to see that all of our results about the equilibrium design of debt contracts and the corresponding profitability conditions remain valid in the framework of the new model. Nevertheless, the incentive compatibility conditions will turn into more complicated expressions. 


\section{$5 \quad$ Profitability Constraints}

Our next step is to assess whether investors are indifferent between long-term debt and outside equity or whether they would prefer one contract over the other. Since holders of contingent rights cannot exercise control unless the manager has failed to make payment, these contracts leave more opportunities for the manager to transfer wealth from investors off the equilibrium path. In particular, a manager planning to default could start milking the assets prior to default. ${ }^{25}$ In our model the manager who plans to default in the second period will choose to make the first payment, but at the same time will skip the investment and will divert these funds in the first period. If this happens, then holders of contingent control rights will have to wait until the second period to discipline the manager. Therefore, these investors will capture less value in strategic default than will investors with unconditional rights. As a consequence, there will be projects which can raise funds by issuing a claim with the unconditional right to dismiss the manager but cannot secure financing by issuing a claim with contingent right to dismiss the manager and to take over the company as a going concern in default.

To see this, we compare the equilibrium strategies and the corresponding incentive compatibility conditions for long-term debt and those for outside equity. In case of equity finance, the following strategies for the equityholders and the managers constitute a subgame perfect equilibrium. ${ }^{26}$

\footnotetext{
${ }^{25}$ Leland (1999) finds that asset substitution is not an issue for the average firm but becomes a severe problem for firms on the verge of default. Fluck, Holtz-Eakin, and Rosen (1997) report that before their businesses fail entrepreneurs start withdrawing funds from their firm at a much faster rate than investors.

${ }^{26}$ See Fluck (1998) for the derivation of this equilibrium.
} 
For equityholders: Equityholders do not replace the manager at first and until the manager paid equilibrium dividends and properly maintained the firm's assets each period. If there is any deviation from the equilibrium, then they replace the manager next period.

For the (new) manager: Pay equilibrium dividends and maintain the assets each period. If there is any deviation from the equilibrium, then divert the cash flows for ever.

For outside equity to be sustainable it must be the case that

$$
\frac{\delta E d}{1-\delta} \geq I
$$

so that equityholders can recover their investment. Furthermore, the present value of all future managerial incentive payments must exceed any realizations of the cash flows. Formally, ${ }^{27}$

$$
\begin{aligned}
& M_{v+x}+\delta \frac{M}{1-\delta} \geq v+x ; \\
& M_{v-x}+\delta \frac{M}{1-\delta} \geq v-x .
\end{aligned}
$$

The main difference between the equilibrium strategies and the incentive compatibility conditions of debt and equity stems from the design of the control rights. While debtholders have contingent control rights, i.e. they can only act if default has occurred, equityholders

\footnotetext{
${ }^{27}$ It is sufficient to focus on these conditions for the comparison of the two contracts. The proof of sufficiency is straightforward by comparing the rest of the incentive compatibility conditions for debt (see Appendix) and the remaining incentive compatibility conditions for outside equity (see Fluck (1998)) and is therefore omitted.
} 
have unconditional control rights, that is they can dismiss the manager regardless of the cash flows.

In comparing debt with equity, we will focus on the perpetual bond from Section 3.3. In contrast to outside equity, this contract is sustainable only if inequalities (6), (7) also hold in addition to (8), (9) and (10). Recall that conditions (6) and (7) capture the notion that the manager may start milking the assets prior to default.

Assuming that investors finance the project if they break even, the inequality-triplets of (1), (2), and (3), and of (8), (9), and (10) coincide in equilibrium. Consequently, if a project can raise debt, it can also raise outside equity but not vice versa.

A comparison of these inequalities reveal that the choice between long-term debt and outside equity depends on the right hand sides of the managerial incentive compatibility conditions and, thereby, on $v, x$, and $I$, the variability of the cash flows, and the profitability of the project. For reasonably high values of $\delta$, two possible cases arise. ${ }^{28}$ In the first scenario $a+\delta v>v+x$. In the second scenario $v-x<a+\delta v \leq v+x$. In neither case, (9) and (10) imply (6) and (7). Thus, for a wide range of parameter values, there are projects that cannot raise longer-term debt but may still raise outside equity. This is so because the profitability threshold for securing longer-term debt is higher than for securing outside equity. These projects have limited financing choice because of higher cash flow variability (high $x$ ) or lower profitability (low $v$ or high $I$ ).

Proposition 4 summarizes the findings on the availability of financing. The proof can be derived from the steps outlined above, and therefore it is omitted.

\footnotetext{
${ }^{28}$ For very low $\delta$ there is also a third case: $a+\delta v \leq v-x$. In this case, if a project can raise outside equity, it can also raise debt and vice versa.
} 
Proposition 4 If the manager can finance his project by issuing long-term debt, then he can also finance the same project by issuing outside equity, but not vice versa.

To illustrate Proposition 2 we present an example of a project that can be financed by outside equity, but not by long-term debt.

\section{Example:}

Let $v$, the periodic expected cash flows of the project, be $100 ; x$, the standard deviation of the cash flows 15; and the investment outlay $I=150$. Then, in the good state, the project yields 115 , and in the bad state, 85 .

Suppose that the discount factor $\delta=0.9$. Given $I$ and $\delta, a=\frac{\delta I}{1+\delta}=71$. After substituting into (8), the expected payment on this contract is $17 .{ }^{29}$

In the bad state, the manager cannot make full payment: After renewing the assets, he is left with only $85-71=14$, so the contractual payment should be set at 20 to assure that investors recover their investment. The manager will default and will pay 14 in the bad state, and as long as he pays 14, he is forgiven for his liquidity default. In the good state, the manager pays 20 in equilibrium.

Correspondingly, the manager enjoys 25 in private benefits in the good state and no private benefits in the bad state. Conditions (9) and (10) hold since substituting into (9) and (10) gives us $132>115$, and $112>85$, respectively. But inequality (6) fails to hold since substituting into $(6)$ we get $132<160$. Consequently, this project can be financed by outside equity, but not by long-term debt.

\footnotetext{
${ }^{29}$ Similar calculations can be provided for debt contracts with maturity T. For these debt contracts the periodic payments would be higher.
} 
Example 1 presents a positive net present value project that cannot raise long-term debt but can raise outside equity. The reason is that this project is not profitable enough to provide sufficient incentive payments for the manager to honor creditors' claim. If long-term debt is ever issued, then the manager would find it optimal not to maintain the assets in the first period when the cash flow realization is high, and to strategically default in the following period. Nevertheless, the manager can raise financing by issuing outside equity. This finding is consistent with empirical evidence that firms are substantially larger when they have their first public debt issue than when they have their first public equity issue (Carey et al. (1993)).

Worth noting that as long as the investment policy is nonverifiable, writing a covenant in the contract cannot make it any easier for the manager to raise debt financing. In contrast, if the managerial investment policy is verifiable, then covenant debt will do just as well in preventing wealth transfer by management as outside equity.

\section{Conclusion}

This paper shows that the debtholders' right to dismiss the manager and take over the firm as a going concern in default can induce the manager to make repeated investments over time and, therefore, it can sustain debt contracts with maturity longer than the life of the

firm's existing physical assets. Since holders of contingent control rights can only discipline the manager upon default, long-term debt allows more opportunities for wealth transfer from investors to the manager than outside equity. As a consequence, an entrepreneur who can raise funds by issuing outside equity might not be able to secure financing by long-term debt. 
To the extent that more projects have access to outside equity than to debt financing, our model is consistent with Stulz (1990), who finds that outside equity has an advantage over debt in alleviating underinvestment.

\section{Appendix}

Proof of Proposition 1:

To establish that the contract is sustainable we need to check whether (A) investors are willing to finance the project ex ante in exchange for periodic payments; (B) investors are willing to keep the manager in liquidity default; (C) investors are willing to dismiss the manager and take over the firm in strategic default; (D) the manager is willing to make payments and to periodically renew the assets if he has not strategically defaulted; (E) the replacement manager is willing to make payments and periodically renew the assets if investors have taken over the company at the time of his arrival and if he has not strategically

defaulted since; $(\mathrm{F})$ the manager will keep diverting the cash flows each period following a strategic default; $(\mathrm{G})$ the manager will divert the cash flows next period if the firm has been taken over following a liquidity default; $(\mathrm{H})$ the new manager will divert the cash flows next period if the firm has not been taken over at the time of his arrival.

We will present the corresponding incentive compatibility constraints below.

(A) Investors are willing to finance the project if (1) holds.

(B) Investors are willing to keep the manager and extend the maturity of the debt in a liquidity default rather than dismiss him if $\forall 0 \leq \tau<T$ 


$$
\sum_{t=\tau+1}^{T+1} \delta^{t-\tau} E p_{t} \geq-c+\sum_{t=\tau+1}^{T+1} \delta^{t-\tau} E \hat{p}_{t}
$$

Investors will keep the manager and extend the maturity of the debt ${ }^{30}$ in liquidity default rather than dismiss him and take over the company if $\forall 0 \leq \tau<T$

$$
\sum_{t=\tau+1}^{T+1} \delta^{t-\tau} E p_{t} \geq \frac{E \hat{p}^{+}}{1-\delta}-c
$$

(C) Investors are willing to dismiss the manager, provide $I$ and write a new debt contract for the renewal of the assets and take equity in exchange for their remaining claim in a strategic default at time $\tau,{ }^{31}$ rather than keep him and refinance the project or keep him and do nothing if $\forall 0 \leq \tau<T$

$$
\begin{gathered}
-I+\sum_{t=\tau+1}^{T+\tau} \delta^{t-\tau} E \hat{p}_{t}+\frac{E \hat{p}^{+}}{1-\delta}-c \geq-I \\
-I+\sum_{t=\tau+1}^{T+\tau} \delta^{t-\tau} E \hat{p}_{t}+\frac{E \hat{p}^{+}}{1-\delta}-c \geq 0 .
\end{gathered}
$$

(D) The manager is willing to make payments and to periodically renew the assets if (2)-(5) hold.

(E) The incoming manager is willing to make payments and to periodically renew the assets if investors have taken over the company at the time of his arrival and if he has not strategically defaulted, if

\footnotetext{
${ }^{30}$ If investors did not have the ability to extend the debt in default, then they would take over the company in liquidity default as well as in strategic default.

${ }^{31}$ It is sufficient to consider only the two-step default strategy here, since this strategy makes the investors worst off.
} 


$$
\begin{aligned}
& \hat{M}_{v+x}+E \hat{M} \sum_{t=\tau+1}^{T} \delta^{t-\tau}+\delta^{T-\tau+1} \hat{M}^{\infty} \geq v+x \\
& \hat{M}_{v-x}+E \hat{M} \sum_{t=\tau+1}^{T} \delta^{t-\tau}+\delta^{T-\tau+1} \hat{M}^{\infty} \geq v-x \\
& \hat{M}_{v+x}+E \hat{M} \sum_{t=\tau+1}^{T} \delta^{t-\tau}+\delta^{T-\tau+1} \hat{M}^{\infty} \geq a+\delta v \\
& \hat{M}_{v-x}+E \hat{M} \sum_{t=\tau+1}^{T} \delta^{t-\tau}+\delta^{T-\tau+1} \hat{M}^{\infty} \geq a+\delta v .
\end{aligned}
$$

(F) Given that investors will dismiss the manager following a strategic default and will keep dismissing him thereafter, the manager will keep diverting the cash flows each period following a strategic default since $v+x \geq M_{v+x}$ and $v-x \geq M_{v-x}$.

(G) Given that investors will dismiss the manager if the firm has been taken over following a liquidity default, the manager will divert the cash flows next period since $v+x \geq M_{v+x}$ and $v-x \geq M_{v-x}$.

(H) Given that investors will dismiss the new manager if the firm has not been taken over following a default, the new manager will divert the cash flows next period since $v+x \geq \hat{M}_{v+x}$ and $v-x \geq \hat{M}_{v-x}$.

\section{Proof of Proposition 2:}

To establish that this contract is sustainable we need to check whether $(\mathrm{A})$ investors are willing to finance the project ex ante in exchange for periodic payments; (B) investors are willing to keep the manager and extend the maturity of the debt in liquidity default; (C) 
investors are willing to dismiss the manager and extend the maturity of the debt in strategic default; (D) the manager is willing to make payments and to periodically renew the assets if he has not strategically defaulted; (E) the replacement manager is willing to make payments and periodically renew the assets if he has not strategically defaulted; $(\mathrm{F})$ the manager will keep diverting the cash flows each period following a strategic default; $(\mathrm{G})$ the new manager will divert the cash flows if the maturity of the debt has not been extended by the time of his arrival.

The corresponding incentive compatibility conditions are presented below.

(A) Investors are willing to finance the project if (1) holds.

(B) Investors are willing to keep the manager and extend the maturity of the debt in a liquidity default rather than dismiss him if $\forall 0 \leq \tau<T$ if (14) holds.

(C) Investors are willing to dismiss the manager, provide $I$ and write a new debt contract for the renewal of the assets and extend the maturity of the debt in a strategic default rather than keep him and refinance the project or keep him and do nothing if $\forall 0 \leq \tau<T$

$$
\begin{gathered}
-I+\sum_{t=\tau+1}^{T+\tau} \delta^{t-\tau} E \hat{p}_{t}-c \geq-I ; \\
-I+\sum_{t=\tau+1}^{T+\tau} \delta^{t-\tau} E \hat{p}_{t}-c \geq 0 .
\end{gathered}
$$

(D) The manager is willing to make payments and to periodically renew the assets if (2)-(5) hold.

(E) The incoming manager is willing to make payments and to periodically renew the assets if he has not strategically defaulted, if $\forall 0 \leq \tau<T$ (18), (19), (20) and (21) hold. 
(F) Given that investors will dismiss the manager upon a strategic default and will keep dismissing him thereafter, the manager will keep diverting the cash flows each period following a strategic default, since $v+x \geq M_{v+x}$ and $v-x \geq M_{v-x}$.

(G) Given that investors will dismiss the new manager if the firm has not been taken over following a default, the new manager will divert the cash flows next period since $v+x \geq \hat{M}_{v+x}$ and $v-x \geq \hat{M}_{v-x}$.

\section{Proof of Proposition 3:}

To establish that this contract is sustainable we need to check whether (A) investors are willing to finance the project ex ante in exchange for periodic payments; (B) investors are willing to keep the manager in liquidity default; $(\mathrm{C})$ investors are willing to dismiss the manager in strategic default; (D) the manager is willing to make payments and to periodically renew the assets if he has not strategically defaulted; (E) the replacement manager is willing to make payments and periodically renew the assets if he has not strategically defaulted; (F) the manager will keep diverting the cash flows each period following a strategic default. The corresponding incentive compatibility conditions follow.

(A) Investors are willing to finance the project if (8) holds.

(B) Investors are willing to keep the manager rather than dismiss him if

$$
\sum_{t=1}^{\infty} \delta^{t} E p_{t} \geq-c+\sum_{t=1}^{\infty} \delta^{t} E \hat{p}_{t} .
$$

(C) Investors are willing to dismiss the manager, provide $I$ and write a new debt contract for the renewal of the assets in a strategic default, ${ }^{32}$ rather than keep him and refinance the

\footnotetext{
${ }^{32}$ It is sufficient to consider only the two-step default strategy here, since this strategy makes the investors worst off.
} 
project or keep him and do nothing, if

$$
\begin{gathered}
-I+\frac{\delta E \hat{p}_{t}}{1-\delta}-c \geq-I . \\
-I+\frac{\delta E \hat{p}_{t}}{1-\delta}-c \geq 0 .
\end{gathered}
$$

(D) The manager is willing to make payments and to periodically renew the assets if (6), (7), (9) and (10) hold.

(E) The incoming manager is willing to make payments and to periodically renew the assets if he has not strategically defaulted, if

$$
\begin{gathered}
\hat{M}_{v+x}+\frac{\delta E \hat{M}}{1-\delta} \geq v+x \\
\hat{M}_{v-x}+\frac{\delta E \hat{M}}{1-\delta} \geq v-x \\
\hat{M}_{v+x}+\frac{\delta E \hat{M}}{1-\delta} \geq a+\delta v \\
\hat{M}_{v-x}+\frac{\delta E \hat{M}}{1-\delta} \geq a+\delta v
\end{gathered}
$$

(F) Given that investors will dismiss the manager upon a strategic default and given that if they failed to dismiss the manager in a strategic default right away, they will dismiss him in the following period regardless of payment made, the manager who has strategically defaulted will keep diverting the cash flows each period thereafter, since $v+x \geq M_{v+x}$ and $v-x \geq M_{v-x}$ 


\section{References}

[1] American Bar Foundation, 1971, Commentaries on Model Debenture Indenture Provisions 1965, Model Debenture Indenture Provisions All Registered Issues 1967, and Certain Negotiable Provisions Which May Be Included in a Particular Incorporating Indenture, Chicago, Il.

[2] Amihud, Y., Garbade, K. and M. Kahan, 1999, "A New Governance Structure for Corporate Bonds," Stanford Law Review, 51, 447-492.

[3] Barclay, M. and C. Smith, 1995, "The Maturity Structure of Corporate Debt," Journal of Finance, 50, 609-631.

[4] Berglöf, E. and E. von Thadden, 1994, "Short-term versus Long-term Interests: Capital Structure with Multiple Investors," The Quarterly Journal of Economics, 109, 10551084.

[5] Beneish, M. D. and E. Press, 1993, "Costs of Technical Violations of Accounting-Based Debt Covenants," Accounting Review, 68, 229-253.

[6] Berkovitch, E. and H. Kim, 1990, "Financial Contracting and Leverage Induced Overand Under-Investment Incentives," Journal of Finance, 45, 765-794.

[7] Berkovitch, E. and R. Israel, 1996, "The Design of Internal Control and Capital Structure," Review of Financial Studies, 9, 209-240.

[8] Bolton, P. and D. Scharfstein, 1990, "A Theory of Predation Based on Agency Problems in Financial Contracting," American Economic Review, 80, 93-106. 
[9] Boot, A., S. I. Greenbaum and A. Thakor, 1993, "Reputation and Discretion in Financial Contracting," American Economic Review, 83, 1165-1183.

[10] Carey, M., S. Prowse, J. Rea, and G. Udell, 1993, "The Economics of Private Placements: A New Look," Financial Markets, Institutions and Instruments, 2, 1-67.

[11] Chemmanur, T. and P. Fulghieri, 1994, "Investment Bank Reputation, Information Production and Financial Intermediation," Journal of Finance, 49, 57-79.

[12] Chemmanur, T. and P. Fulghieri, 1994, "Reputation, Renegotiation, and the Choice Between Bank Loans and Publicly Traded Debt," Review of Financial Studies, 7, 475506.

[13] Chen, K. C. W. and K. C. J. Wei, 1993, "Creditors' Decision to Waive Violations of Accounting-based Covenants," Accounting Review, 68, 211-228.

[14] Dewatripont, M. and J. Tirole, 1994, "A Theory of Debt and Equity: Diversity of Securities and Management-Shareholder Congruence," The Quarterly Journal of Economics, 109, 1027-1054.

[15] Diamond, D., 1984, "Financial Intermediation and Delegated Monitoring," Review of Economic Studies, 51, 393-414.

[16] Fluck, Z., 1998, "Optimal Financial Contracting: Debt versus Outside Equity," Review of Financial Studies, 11, 383-419.

[17] Fluck, Z., D. Holtz-Eakin, and H. Rosen, 1997, Where Does the Money Come From: The Financing of Small Entrepreneurial Enterprises, mimeo, Princeton University. 
[18] Franks, J. and W. Torous, 1993, "An Empirical Investigation of US Firms in Reorganization", in E. Altman (ed) Bankruptcy and Distressed Restructurings, Business One Irwin, Homewood, Ill.

[19] Franks, J. and W. Torous, 1994, "A Comparison of Financial Recontracting in Distressed Exchanges and Chapter 11 Reorganizations," Journal of Finance, 35, 349-370.

[20] Franks, J., K. Nyborg and W. Torous, 1996, " A Comparison of US, UK and German Insolvency Codes," Financial Management, 86-101.

[21] Franks, J. and O. Sussman, 1999, Financial Innovation and Corporate Insolvency, Working Paper, London Business School.

[22] Gale, D. and M. Hellwig, 1985, "Incentive Compatible Debt Contracts: The One-Period Problem," Review of Economic Studies, 52, 647-663.

[23] Gavish, B. and A. Kalay, 1983, "On the Asset Substitution Problem", Journal of Financial and Quantitative Analysis, 18, 21-30.

[24] Gilson, S., 1990, "Bankruptcy, Boards and Blockholders," Journal of Financial Economics, 27, 275-312.

[25] Gilson, S., 1993, "Management Turnover and Financial Distress," in E. Altman (ed) Bankruptcy and Distressed Restructurings, Business One Irwin, Homewood, Ill.

[26] Gilson, S., K. John and L. H. P. Lang, 1990, "Troubled Debt Restructurings: An Empirical Study of Private Reorganizations of Firms in Default," Journal of Financial Economics, 27, 315-353. 
[27] Grossman, S. and O. Hart, 1986, "The Costs and Benefits of Ownership: A Theory of Vertical Integration," Journal of Political Economy, 94, 691-719.

[28] Hart, O. and J. H. Moore, 1989, "Default and Renegotiation: A Dynamic Model of Debt," mimeo, Massachussetss Institute of Technology.

[29] Hart, O. and J. H. Moore, 1994, "A Theory of Debt based on the Inalienability of Human Capital," The Quarterly Journal of Economics, 109, 841-880.

[30] Hart, O. and J. H. Moore, 1995, "Debt and Seniority: An Analysis of Hard Claims in Constraining Management," American Economic Review, 85, 567-585.

[31] James, C., 1995, "When Do Banks Take Equity in Debt Restructurings?," Review of Financial Studies, 8, 1209-1234.

[32] Jensen, M. C. and W. H. Meckling, 1976, "Theory of the Firm: Managerial Behavior, Agency Costs and Capital Structure," Journal of Financial Economics, 305-360.

[33] John, K., 1993, "Managing Distress and Valuing Distressed Securities: A Survey and Research Agenda," Financial Management, 22, 60-78.

[34] Kahan, M. and B. Tuckman, 1996, "Private versus Public Lending: Evidence from Covenants," in J. D. Finnerty and M. S. Fridson (eds), The Yearbook of Fixed Income Investing.

[35] Leland, H. E., 1999, Agency Costs, Risk Management, and Capital Structure, Working Paper, University of California, Berkeley.

[36] Mayer, C., 1999, Private communication. 
[37] Modigliani, F. and M. Miller, 1958, "The Cost of Capital, Corporation Finance, and the Theory of Investment," American Economic Review, 48, 261-297.

[38] Myers, S., 1977, "The Determinants of Corporate Borrowing," Journal of Financial Economics, 147-176.

[39] Myers, S., 1998, Outside Equity Financing, Working Paper, Sloan School of Management, MIT.

[40] Saunders, A., 1997, Financial Institution Management, Irwin Press, Chicago, Il.

[41] Smith C. and J. Warner, 1979, "On Financial Contracting: An Analysis of Bond Covenants," Journal of Financial Economics, 7, 117-161.

[42] Stochs, M. and D. Mauer, 1996, "The Determinants of Corporate Debt Maturity Structure," Journal of Business, 69, 279-312.

[43] Stulz, R., 1990, "Managerial Discretion and Optimal Financing Policies," Journal of Financial Economics, 26, 3-27.

[44] Sweeney, A. M., 1994, "Debt Covenant Violations and Manager's Accounting Responses," Journal of Accounting and Economics, 17, 270-285.

[45] Townsend, R., 1979, "Optimal Contracts and Competitive Markets with Costly State Verification," Journal of Economic Theory, 21, 265-293. 